\title{
Varieties of populism: insights from the Italian case
}

\author{
MANUELA CAIANI ${ }^{1}$ AND PAOLO R. GRAZIANO ${ }^{2 *}$ \\ ${ }^{1}$ Scuola Normale Superiore, Institute of Humanities and Social Sciences, Florence, Italy \\ ${ }^{2}$ Department of Political Science, Law and International Studies, Università degli Studi di Padova, Padua, Italy
}

\begin{abstract}
Academic attention to populism has sharply increased in recent years. Yet, a commonly accepted definition is still lacking, with scholars disagreeing on categorization, labels, and boundaries between its different manifestations. In this article, through an analysis of Euromanifestos and party statutes, we address the interactions between Italian political parties and populism by adopting the various definitions available in populism theory, that is, populism as (i) ideology, (ii) rhetoric, (iii) communication style, and (iv) organization. Our aim is to identify all major attributes linked to populism and empirically investigate them with lower level indicators, measuring and comparing them across Italian parties and over time. The empirical analysis, conducted through a formalized content analysis of the European electoral programmes and party statutes, considers populism not as a discrete concept but rather as a continuous one and therefore enables us to undercover the variety of populisms within the Italian parties. The main finding of the article is that over the last decades all Italian parties have shown some signs of populism and that the intensification of populist features is strongly linked to the exarcebation of the financial and economic crisis, and its governance.
\end{abstract}

Keywords: populism; European Union; political parties; Italy

\section{Introduction: populism: a contested definition}

Academic attention to populism has sharply increased in recent years (e.g. Verney and Bosco, 2013; Kriesi, 2014). Yet, a commonly accepted definition is still lacking, with scholars disagreeing on categorization, labels, and boundaries between its different manifestations (Mudde, 2004). Some authors also stress that there is an abuse of this term in the public discourse. More specifically, one of the difficulties regarding the definition of populism is that it has been applied (and adapted) to several very different historical phenomena (movements, parties, regimes, intellectuals), across various periods, and often it has been used in a pejorative tone. In this article, we address the interactions between Italian political parties and populism, understood as an analytical tool, through an investigation of Euromanifestos (from 2004 to 2014$)^{1}$ and party statutes. From a theoretical perspective, populism has

${ }^{1}$ We used the Euromanifesto data gathered by the University of Mannheim.

*E-mail: paoloroberto.graziano@unipd.it; manuela.caiani@sns.it 
been conceptualized as (see also Caiani and della Porta, 2011) (i) a political rhetoric that is marked by the 'unscrupulous use and instrumentalization of diffuse public sentiments of anxiety and disenchantment' (Betz, 1994: 4) and appeals to 'the power of the common people in order to challenge the legitimacy of the current political establishment' (Abt and Rummens, 2007: 407); or as (ii) a 'thin' or 'weak' ideology, that considers 'society to be ultimately separated in two homogeneous and antagonistic groups: 'the pure people' vs. 'the corrupt elite', and which argues that politics should be an expression of the volonté générale of the people' (Mudde, 2004: 543). Elements of this 'thin-centered ideology' (Freeden, 1998) concerning the structure of power in society are the references to antagonistic relations between the people and the elite, the idea of restoring popular sovereignty, and a conception of the people as a homogeneous body. A specific feature of this ideology is its 'indeterminancy' that 'responds to its need to be adaptable' (Ruzza and Fella, 2009: 3). Finally, populism has been also defined as (iii) a type of organization, characterized by the presence of a charismatic (new kind of) leadership (Taggart, 2000; Eatwell, 2003), and (iv) a special style of communication (Tarchi, 2002; Jagers and Walgrave, 2007), namely without intermediaries. In particular, the presence of a charismatic leader - such as Haider, Le Pen, Bossi, Salvini, and others - adopting a certain style and rhetoric (Mazzoleni, 2003) is seen as a crucial characteristic of populism (Pasquino, 2008). Populists are successful due to their role as 'taboo breakers and fighters against political correctness' (Mudde, 2004: 554). They usually appeal to emotions of fear and enthusiasm (by employing higly emotional, slogan-based, tabloid-style language), adopt a demagogic style, and refer to resentment, offering easy solutions for complex problems, and combining 'verbal radicalism and symbolic politics with the tools of contemporary political marketing to disseminate their ideas among the electorate' (Mazzoleni et al., 2003).

Definitions of the concept, however, generally converge in seeing as a core aspect of populism its focus on 'the people'. Populist movements attempt to create a direct connection between the people and the political power, bypassing the electoral process. They often consider the people's aspirations to be betrayed by corrupt political elites (politicians both from the government and the opposition) (Rydgren, 2007) and suspect that a conspiracy against the people is taking place (Taggart, 2000). The charismatic leader ('the savior') is the only one who embodies the will of the 'common people' and is able to speak on their behalf. However, also the very definition of the 'people' remains ambiguous in the use of populists, and competing interpretations try to clarify who 'the people' actually are. Indeed, some see the people in terms of class or ethnicity (e.g. Di Tella, 1997; Mény and Surel, 2002), whilst others refer to 'the heartland', namely a place in which 'in the populist imagination, a virtuous and unified population resides' (Taggart, 2000: 95).

Moving from theoretical definitions to empirical cases, one is impressed by the enormous variety of populist movements (Luther, 2003; Tarchi, 2015), which may be very differentiated. For example, if a typological criterion is adopted, we can distinguish between right-wing and left-wing populist movements. Whereas the 
latter identify the 'people' in socio-economic terms, such as the working class exploited by the bourgeois elite, the former refer to the ethnic nation (Abts and Rummens, 2007). Today, populism is above all found on the extreme or radical right (e.g. the Austrian Freedom Party, the French National Front, etc.) (Mudde, 2002; Rydgren, 2003; Laycock, 2005) but it can also be related to the radical left (e.g. March, 2007; Zaslove, 2008). Beyond populism on the fringes of the political spectrum, observers also underline the increasing importance in Western Europe of a type of 'mainstream populism' (e.g. Tony Blair in the United Kingdom, see Mair, 2002), as well as a 'centre-right populism', considering for instance Silvio Berlusconi one of the best examples in Europe of this category (e.g. Campus, 2006; Pasquino, 2007). In this article, we will consider all these four main dimensions of populism - political rhetoric, ideology, type of organization, and style of communication - testing their empirical applicability on the Italian case. Our analysis suggests that a combination of these key elements is better than mutually exclusive (dichotomic) definitions, as it can shed new light on a variety of different forms of populism and be applied more generally across different contexts and times.

\section{Research design: concepts, methods, and case selection}

Taking into account these scholarly reflections, our article aims to appraise the 'degree of populism' within Italian political parties with a particular focus - linked to the overarching topic of the special issue - on the European elections. Our key leading research questions are as follows: How 'much' populist are Italian parties? Which parties are populist? Only those that traditionally are defined as such or also the mainstream ones? Are there degrees of populism? In general, and beyond the Italian case, an empirical analysis of populism seems particularly useful as the literature on populism is 'populated' with several definitions under the form of specific attributes in order to categorize parties as populist or not (in a dichotomous manner), but there still is limited empirical research about how concretely parties may put together the various 'populist' attributes. This article aims at filling this gap, starting with the Italian case. More specifically, the added value of this article is to adopt a 'radial' conceptualization of populism which can have a minimal and all-encompassing definition such as: (a) an ideology which thematizes the virtues of the 'people' against the 'establishment' or the 'ruling elite'; (b) a rhetoric which emphasizes the delegitimation of the old political actors and their proposals, and legitimizes the new political actors; (c) a communication style which is non-institutional and informal, and offers easy solutions to complex problems; (d) an organization characterized by a concentration of party power in the hands of a leader and by a personalization of party/leader - party/members relationship. Each of these dimensions will be considered in our study to 'measure' the degree of populism in the Italian parties, through an in depth content analysis of the Euromanifestos and party statutes.

For example, for populism as rhetoric, we have developed three indicators. In particular, there must (1) be delegitimation of political institutions and other 
political actors and their proposals; (2) instrumentalization of diffuse public sentiments of anxiety and disenchantment; (3) legitimation of new political actors (i.e. the so-called sublimation of the 'redemptive' side of politics - Canovan, 1999). For populism as an ideology, (1) there must be references to 'the people' (or 'common people', 'ordinary men') whose interest are said to be represented by the populist party; (2) manifestos have to include proposals to create a direct relationship between the people and the power holders; (3) they have to contain antagonistic relations between the people and the elite (i.e. anti-establishment or anti-elite statements), etc. (for more details on the codebok used, the indicators elaborated for these four dimensions and their measurements, see Table A1 in the Appendix).

In other words, this article uses the many definitions available in populism theory to identify all major attributes linked to populism and empirically investigates them (with lower level indicators), measuring and comparing them across italian parties and over time. This allows the appreciation of populism not as a 'static status' (generally considered pathologic) that a party may have or not have, rather as an observable (and 'measurable') phenomenon which may concern all political parties present in a given domestic political community.

Although this is an exploratory research effort, we are also guided by the hypothesis that we should expect growing populist features due to the presence after 2008 - of an 'exogenous shock' such as the financial and economic crisis. We focussed on the seven electorally most relevant parties which over the years have obtained seats in the European Parliament: the Northern League (NL), Unione di Centro (UDC), Italia dei Valori (IDV), Forza Italia (FI), Partito Democratico, Rifondazione Comunista (RIF)/Tsipras, and the Five Star Movement (FSM). ${ }^{2}$

From a methodological standpoint, through yoshikoder - an automated manifesto for textual analysis - we have conducted a formalized content analysis of the European electoral manifestos (2004-14) and party statutes, which have been used extensively for analyses in order to understand the role and strenght of party leaders. We have attributed a score (0-1) for each indicator and calculated the overall score per dimension (per party per year) in order to compare the dimensions across parties and years (and build an additive, 'index of populism'). In the qualitative part of our analysis, we have also taken into consideration further specifications for each variable (e.g. people), such as for instance the description of people done by the populist party (the so-called 'linguistic qualifiers'), as adjectives or adverbials. As for the analysis of the party statutes, the degree of personalization of the party (dimension organization, indicator 'leader power by statute') has been detected using the following coding criteria: rules for the election/removal of the leader; tasks (decision-making) of the leader vs. other party bodies; rules for membership and member participation opportunities.

\footnotetext{
${ }^{2}$ Due to space constraints, we have moved the detailed analysis of the UDC and IDV parties in the Appendix (Tables B and C), although we did include their numerical scores in our Table 6.
} 
In sum, our relative (within the same party across years, and across parties in the same year) and continuous conceptualization of populism allows for variations among parties concerning their level of populism on each of the four dimensions (for a similar attempt see de Raadt et al., 2004).

We consider that applying our analysis to the European manifestos is particularly fruitful as it may also shed a new light on Euroscepticism, especially in view of the fact that populism and Euroscepticism are increasingly discussed, sometimes as interrelated phenomena, in academic and political interpretations of current challenges to liberal democracies (Mudde, 2004; Carlotti, 2015). For example, the conceptualization of the 'pure people versus the corrupt elite', can be used to look at the discourse of several Eurosceptic parties within the European Parliament (see e.g. Nigel Farage's intervention at the European Parliament in 2010 and his frequent reference to 'we' conceived not as the British people but as a general 'the people', a 'heartland' that represents an idealized conception of the community; Taggart, 2004: 274).

Moreover, the re-conceptualization of the notion of Euroscepticism as a rhetoric-like populism has been proposed by some scholars, as Leconte, who suggests to look at the European Union (EU) first as a subject for myths, depicting the 'EU as a regulatory monster' against citizens' ordinary life, second as a fertile ground for the rhetoric of the 'us vs. them' (Leconte, 2015: 258). Finally, both populism and Euroscepticism can be scrutinized through the lens of political protest, as for example Canovan (1999) proposes. As already mentioned in the opening section, populism has often been addressed as a pathology (or a shadow of it, at best) of modern democracies such as in the case of Euroscepticism, whereas we will consider it as a political phenomenon to be understood and not as a pathology to be overcome.

In what follows, the empirical analysis (through electoral manifestos and statutes) of the degree of populism within Italian parties will be conducted (third section), underlining similarities and differences across party and within parties across time (fourth section), and linking, in the conclusion (fifth section), our main findings to the relevant literature within which this article can be located.

\section{Populism in context: European elections and Italian political parties}

The 2014 European parliamentary elections have been depicted by many commentators as a 'political earthquake', due to the striking consensus obtained by Eurosceptic and populist parties across Europe (Carlotti, 2015). Taken together, it has been calculated that 212 of the 715 Members of the European Parliament (MEPs) belong to Eurosceptic parties for a total of $28 \%$ of seats (a significant increase with respect to the previous European elections) (Treib, 2014). Populist parties have recently increased their electoral and social penetration everywhere in and outside the EU. In the last 2014 European elections, right-wing populist parties strengthened their position in an unprecedented way: for example, the Front National in France gained $25 \%$ of votes and 24 seats (against $6.4 \%$ of 2009); 
United Kingdom Independence Party (UKIP) in Great Britain gained 37\% of votes and 22 seats $(>10 \%$ than in 2009); in Denmark the People's Party triumphed becoming one of the most powerful right-wing populist party of Northen Europe, doubling its number of MPEs from 2 to 4 . In Hungary, the neofascist formation Jobbik scored the 15\% (maintaining invariated its support with respect 2009) and in the Netherlands, Geert Wilders' Europhobic PVV gained four MEPs, with around $13 \%$ of votes $(-3 \%$ than in 2009$)$. Within this general tendency of populist parties strengthening across the EU, the Italian case appears as particularly interesting for analysis, as it is characterized by a prolonged presence of populist parties in government which has challenged the established party system (Albertazzi and McDonnell, 2015).

\section{The NL: electoral manifestos and party statute}

In terms of populism as ideology, the populist 'us'-'them' pattern is clearly visible in all the three electoral manifestos of the NL (see Table 1). The category of 'people' is prominent in presence, although decreasing (from 44 references in 2004, to 25 in 2009 to six in 2014). In addition, also its characteristics change across the years, from a 'people' ethnically defined as 'North' and 'Padano' to (already since the 2009 manifesto) a people of the North, defined mainly in economic terms, on the one hand, and 'European peoples', characterized in cultural-identitarian terms, on the other hand (i.e. christians vs. muslims: 'Turkey', considered as 'historically and culturally not European', recurs more than 30 times in the 2009 as well as in the 2014 manifesto). Indeed, the reference to the 'North' disappears in 2014. But the NL's discourse has also become increasingly nationalistic with respect to global and European phenomena, so it also accommodates a defence of the Italian people from outside pressures (e.g. the 'them' category 'other countries', which represent those that want to exploit economically Italy, double its presence from 2004 to 2014).

The discourse of the NL frames the people in a way, which significantly converges with the definitions of populism presented above. The NL represents the 'people' as inherently pure and victims of corrupt 'elites'. The theme of the party's self-identification with the people is also present here ('the Northern League is the voice of the people') together with the typical populist idea of the party being called to fight a historical battle to rescue its people (Rydgren, 2007).

The NL extends the 'us'-'them' scheme to the European level: the elites which oppress the people are the European ones (the 'technocratic elites', 'antidemocratic', representative of a 'totalitarian regime', 'medieval empire', 'far and obscure entity, but not abstract!'). Only ranked second are there the domestic politicians, which are always pictured as 'puppets' in the hand of the 'bureaucrats' of Bruxelles, conniving or, at best, naives ('buonisti'), which open the frontiers of the country to immigration. The NL contrasts two 'Europes': the Europe of peoples, which are naturally wise and virtuous, with the 'Europe of institutions' particularly the European Commission (EC), the European Central Bank (ECB); 
Table 1. Northern League (NL): ideological dimension

\begin{tabular}{lrlr}
\hline \hline 'Us' & $N$ & 'Them' & $N$ \\
\hline 2004 & & & 58 \\
Northeners (padani) & 52 & EU & 24 \\
Europe & 45 & Politics/politicians & 18 \\
NL & 40 & Global/mondial/them/multinationals & 14 \\
Peoples/people & 44 & Other countries (USA, etc.) & 13 \\
Common localities/regions & 33 & Turkey & \\
Countries (member, third world) & 20 & & 55 \\
2009 & & & 41 \\
NL & 113 & EU & 31 \\
Our/country & 74 & Euro & 30 \\
Territory & 59 & Government/Roma/Roman(s) & 20 \\
Family & 58 & Turkey/mosque & \\
Europe & 48 & Globalization/international finance & \\
Italy & 45 & & \\
North & 28 & & \\
2014 & & & 53 \\
States/state (members, national) & 61 & EU & 38 \\
Our (territory/companies) & 55 & Turkey & \\
Europe & 45 & Countries (third) \\
Italy & 25 & EU Commission & \\
EU Parliament & 20 & & \\
Us (we) & 17 & & \\
NL & 8 & & \\
\hline \hline & & & \\
\hline
\end{tabular}

$\mathrm{EU}=$ European Union.

and the European Court of Justice, which put in danger the rights and survival of the people. The EU process as a whole is represented very negatively (a 'deception') as the product of an anti-democratic global ideology, aiming at the dismantling of the European system of social rights. Indeed, also the element of 'conspiracy' is present in the NL manifesto. The NL (quoted frequently among the 'us' of the discourse, 40 times in 2004, 113 in 2009, and 25 in 2014) presents itself as the party which embodies the 'voice of the people' and fights for them (to the end of 'restore the sovereignty of the people' in the EU), although this relationship appears 'elitist'.

In terms of populism as organization (an aspect which has been analysed mainly through the statutes of the party), a similar picture of a hierarchical relation between the party and its leader on the one hand and the voters on the other emerges: the former being presented like the shepherd which leads the flock, 'the stimulus' for the country, 'the unique political actor which support an Europe that defends the people from the global project, that wakes up to action against a dictatorship'.

In the manifesto of the NL, we also find many indicators of populism as a rhetoric. There is a clear pattern of continuous and explicit delegitimation of the 'others' (the political establishment and political parties), either at the European ('elite non-democratically elected') or at the national level. 
The style is in fact always direct, informal (except for the 2009 manifesto where it assumes a more 'institutional' shape). The typical style of 'taboo breakers', with frequent appeals to enthusiam ('lets' bring back politics in the hands of the people') and fear (people are pictured as at risk of being 'violated' or 'oppressed' by the EU, in need of being 'defended', make 'safe' against 'any form of aggression' and 'external attacks'), as well as apodictic tones (verbs like 'refuse', 'fight', 'battles', 'oppose', referred to the NL, recur 14 times in the 2004 manifesto, and terms like 'unavoidable', 'unacceptable', appear 10 times in the same document).

Looking at the party statute (2015) of the NL allows an additional assessment of the organizational constraints within which the party's President is called to operate. The picture that emerges is that of a personalistic leadership with a non-mediated relation with his voters. Indeed, the President, Umberto Bossi, is 'the founding father of the NL and it is nominated ad vitam'. He is 'guarantor of the unity of the NL, and favours, with any suitable means, the Padanian identity' (Art. 14). The ad vitam nomination renders the President a powerful and charismatic actor within the party, almost invested by a 'divine legitimacy', almost like autocrats, and his role is never overseen by any other body of the party. To sum up, concerning the leader's power by statute, a personalistic leadership plus a hierarchically organized functioning mode charactherize ${ }^{3}$ therefore the NL.

\section{Democratic Party (PD): electoral manifestos and party statute}

The 2004 electoral manifesto for the European elections of the Uniti nell'Ulivo (at the time, the name of the PD) is an 'old-style' political manifesto made up of 59 pages with some very detailed initial considerations on the overall economic and social state of the EU. More specifically (Table 2), from an ideological standpoint the manifesto is aimed at an electorate made of citizens, elderly, families, and - to a lesser extent - workers, migrants (cited six times), unemployed (cited only three times, although the manifesto contains a section devoted to unemployment and growth strategies), migrants (cited six times). There is no direct conceptualization to the 'people' but rather of diverse categories of people such as elderly, workers, etc. Therefore, the most striking aspect of the manifesto is that there is virtually no 'them' in populist terms as the only potental 'enemy' represented in it is 'terrorism' (cited 10 times) since there is no idea of a 'conspiracy' nor of a differentiation in terms of counter-elite. As far as the rhetoric is concerned, there is no sign of delegitimation of institutions (there is, on the contrary, the idea that the EU is a positive anchor to be hooked to) and very limited delegitimation of other political actors such as Berlusconi, cited only three times as an antagonist and seen as the leader

\footnotetext{
${ }^{3}$ Indeed the NL is a 'confederation' territorially composed of regional 'groups'and leaders, where, 'the control on the bodies of territorial delegations and local federations is made according to the principle that the upper level organs/bodies control the lower level organs/entities' (Art. 35).
} 
Table 2. Democratic Party: ideological dimension

\begin{tabular}{lrlr}
\hline \hline 'Us' & N & 'Them' & $N$ \\
\hline 2004 (Uniti nell'Ulivo) & & & \\
Europe/European(s) & 100 & (International) terrorism & 10 \\
Lista Prodi & 58 & & \\
Citizens & 30 & & \\
Children & 26 & & \\
Consumers & 18 & & \\
2009 & 92 & & 5 \\
Europe/European(s) & 20 & Right & \\
Citizens & 10 & & \\
Italy & & & \\
2014 & 88 & & \\
Europe/European(s) & 19 & & \\
Citizens & 12 & & \\
Youth & 6 & & \\
Democrats & & & \\
\hline \hline
\end{tabular}

who has 'worsened the condition of Italy on almost all the (economic) indicators' (p. 3). Furthermore, there is no legitimation of new actors, which could be 'used' against Berlusconi or his party.

Throughout the document there is strong support for the so-called Lista Prodi (which is another name for the electoral list and which puts more emphasis on the leader Prodi) but there is no specific 'populist' style of communication in terms of references to 'hate' or offering easy solutions to complex problems (on the contrary, the detailed manifesto is an illustration of ways of trying to deal in a complex way with complex problems), nor is there any clear appeal to emotions of fear and enthusiasm or a direct and non-institutional communication style. Finally, with respect to the organization, although the Lista Prodi is cited 58 times (so we may argue that there could be some signs of personalization), both the presence and the description of the relationship between leader, party, and electorate is not of a populistic nature as there is no reference to the charismatic figure of the leader as a figure of someone capable of salvific acts.

The 2009 electoral manifesto is clearly influenced by the economic crisis (which appears 18 times as an 'external constraint') and in contrast with the 2004 manifesto, criticism towards the EC is put forward in terms of the management of the crisis. Still, the reference of the manifesto are the citizens and no specific reference to 'people' is made - the only reference to populism is a negative one, that is, the populism of the right is seen as an 'enemy'. In terms of rhetoric, a strong delegitimation of the right starts to occur, and a limited form of delegitimation of the EC also appears. For example, there is a clear reference to the need 'not be fooled by the populism of the right(s)' (p. 5) or a severe critique towards the EC which has not displayed '(a)nswers to the crisis which have been unsatisfactory' (p. 6). 
With respect to the style of communitation there is slightly more reference to an identified fear (the 'crisis') but still the overall reasoning is not simplifying nor is there use of a non-institutional communication style. Furthermore, in terms of organization the PD is cited only six times and never with a 'leadership-based' connotation, nor is there any clear reference to the relationship between leader and party or leader and voters.

The 2014 manifesto is in line with the 2009 manifesto in terms of length and simplification of issue analysis. 'Us' is defined in relation to Europe, or being Europeans (88 times), whereas the only potential enemy is a not better identified 'right' (mentioned five times). There is no anti-elite or anti-establishment discourse, nor is there a definition of the people (zero mentions in the manifesto) in the name of which the party manifesto has been adopted, whereas the financial institutions are seen as responsible of 'excesses' which need to be constrasted.

Also with reference to the rhetoric, unlike the limited signs of delegitimation that were present in the 2009 manifesto, no strong element of delegitimation occurs, nor is there - with respect to the communication style - any specific identifying fear or other elements, which could have made us consider the manifesto as populist. In terms of organization, no reference to 'leadership' capacities is explicitly present in the manifesto. Furthermore, in this electoral manifesto nothing of specific interest to us is said with reference to the relationship leader-party or leader-voters as the leader is not mentioned in terms of centralizing or providing further legitimation to political proposals.

Looking at the party statute of the PD (a 'federal party', as it auto-defines itself, Art.1), allows an assessment of the organizational constraints within which the party's leader is called to operate. The decision-making of the PD includes also the Direzione generale, which implements the indications of the assembly and decides the political direction of the party (Art. 8), composed by 120 members. Hence, from an organizational point of view, the PD's leader can be considered a primus inter pares among the party leadership, as his legitimation, action, and survival in office are dependent of other party's institutions amongst which power is dispersed. In sum, with respect to the rules for the election/removal of the leader, tasks (decisionmaking) of the leader vs. those of other party bodies, and rules for membership and member participation opportunities, no personalistic leadership emerges from the PD statute.

\section{Rifondazione Comunista: electoral manifesto and party statute}

The 2004 electoral manifesto of Rifondazione Comunista (RC)-Sinistra Europea is another long, old-style manifesto (98 pages). Divided into eight sections (from a defense of the welfare state to the illustration of the consequences of a neoliberal order), the manifesto defines an 'us' which is made up primarily by 'workers' (cited 83 in different variants - females, males, etc.), citizens (34), migrants (33), and movements (24), and it is supported by the centrality of 'work' (154 times) 
Table 3. Rifondazione Comunista: ideological dimension

\begin{tabular}{lrlr}
\hline \hline 'Us' & $N$ & 'Them' & $N$ \\
\hline 2004 & & & \\
Work & 154 & (Neo)Liberalism* & 69 \\
Workers & 83 & Capital* & 49 \\
Citizens & 34 & Globalization & 41 \\
Migrants & 33 & & \\
Movements & 24 & & \\
2009 & & Capital* & 6 \\
Europ" & 54 & (Neo)liberalism & \\
Social & 19 & Nato & \\
Crisis & 15 & & 21 \\
Work & 9 & & 20 \\
Left & 9 & Capital* & 6 \\
2014 & & Austerity & \\
Europ" & 189 & (Neo)liberalism & \\
Work & 77 & Nato & \\
Right/s & 73 & & \\
Social & 32 & & \\
Migrants & 19 & & \\
Public & 19 & & \\
\hline \hline
\end{tabular}

(Table 3). Nevertheless, for our purposes the definition of 'us' is not made with reference to an all-inclusive notion of 'people' but rather, in more classic Rokkanian terms, with reference to the 'workers' against 'capital' (under the form of 'neoliberalism' or 'liberalism', which seems to be the main overall enemy - cited 69 times - or capitalism/capital/capitalistic and globalization, cited 49 and 41 times, respectively). Still, the identification of an 'enemy' does not follow a populist ideology as there is no strong, direct anti-establishment, or anti-elite discourse nor any reference to forms of conspiracy. More traditionally, in Schmittian terms, there is a definition of what the political enemy is and why it should be considered so. In terms of the use of rhetoric tools, there is no delegitimation of institutional or political actors, as also Berlusconi (cited four times) and 'neoliberals' are seen as antagonists and not as illegitimate actors (e.g. on p. 19 of the manifesto, neoliberal policies are accused of being responsible for reduced economic growth but they are not accused of being illegitimate). The same applies to the communication style as no reference to a 'hate' discourse is made, nor is there an overall simplification of the solutions offered in order to contrast complex problems. Also with respect to the organization, the leaders are not even mentioned throughout the manifesto, nor are charismatic or taumaturgic qualities supported relevant.

The 2009 electoral manifesto is even less 'populist', if possibile. Some keywords virtually disappear (such as 'capitalism' and similar terms, which are used only five times, or even 'migrants' or 'migration' are less present than in the 2004 electoral manifesto). Whereas in the 2004 electoral manifesto there was a definition 
of 'us', in 2009, there are some references to the 'social' dimension (19 times), to 'workers' and to the 'left' (nine times for both) but there is no clear identification of 'them' in ideological terms. Also with reference to rhetoric tools there is no delegitimation of institutional or political actors as 'liberals' or 'neoliberals', similarly to the 2004 manifesto, are seen as political adversaries rather than unlegitimate actors, and the same applies to the NATO (cited five times in the manifesto). As for the communication style, no traces of a hate discourse can be found, nor - although the 2009 manifesto is much briefer than the 2004 one - could it be said that there is an overall simplification of the solutions offered in order to contrast complex problems. Furthermore, there is no use of terms which may be associated with resentment or hate as the overall tone is one of mild confrontation on policy issues: against inequality, and in favour of redistribution. Finally, with respect to the organization, no leaders are mentioned throughout the manifesto and a universal, non-personalized discourse is what characterizes the overall content of the manifesto of Un'altra Europa.

The 2014 electoral manifesto (which is a manifesto of an electoral cartel which goes beyond RC and includes also other left parties) is possibly the only one that has some (although very limited) traces of populism, especially in the ideological and organizational dimension. With respect to ideology, there is to some extent a more specific definition of 'us' in terms of Europeans (still a bit vague, though), work and workers (cited all together 77 times), with growing reference to the 'social' dimension (32 times), and to migrants (19 times). The 'them' dimension is not well defined, as the 'usual general suspects' are mentioned - such as (neo)liberalism (20) and NATO (six times), together with austerity (20 times). Put differently, there is a limited identification of 'them' such as the 'establishment' or similar references, which go under the label of 'neoliberals'.

As far as rhetoric is concerned, there is no clear delegitimation of institutional or political actors as - once again - (neo)liberals, capital, and capitalists, NATO are considered to be enemies rather than unlegitimate actors. For example, there is a will to 'overcome NATO', considering it as a legitimate but disputable organization, which has been wrongly supported by European and US governments. With respect to the style of communication, there still is no evidence of 'hate' discourse, and no oversimplification of the solutions can be identified (actually, the 2014 manifesto is by far more articulated and complex than the 2009 one). For example, 'hate' and 'fear' are not words which appear in the manifesto. From an organizational perspective, some timid signs of populism can be found in the references to Tsipras (five times) who is considered to be the 'unifier' of the Greek left and also the inspiration for the unification of the Italian left. Within the statute, there is a clear refusal of leadership-based forms of organization: 'The Partito della Rifondazione Comunista fights against every attitude within the top party bureaucrats and institutional representatives to become separate groups aiming at the search of prestigious roles and material priviledges' (Art. 4). Similarly, to the PD statute, no mention is made of a specific leader, as the internal party life is regulated by general 
rules, which guarantee a democratic life and party sovereignty lies in the hands of the party members. In sum, in terms of leader power by statute, no specific concentration of power in the hands of the leader is foreseen and therefore no signs of populist leadership emerge. More specifically, if we look at the rules for the election/removal of the leader, the tasks (decision-making) of the leader vs. other party bodies, and the rules for membership and member participation opportunities it seems quite clear that no personalistic leadership emerges.

\section{The Five Star Movement: electoral manifestos and statute}

The Five Star Movement (FSM) has not participated in European elections prior to 2014. Analysing the electoral manifesto (Table 4), within the ideological dimension there is a clear definition of what 'them' is, whilst the notion of 'us' remains quite vague. The main identification of 'us' is Italy (18 times), the 'nation' (14 times), and 'FSM' is linked to the 12 times the term movement appears in the document analysis, while the notions of 'community', 'people', and citizens are strongly associated to those who need to 'resist' to/'them' (ECB, International Monetary Fund, World Bank, the EU, other Italian parties, Germany, the international financial actors, neoliberals). In terms of rhetoric, there is a strong tendency to delegitimize other actors and legitimize new actors, such the Movimento itself: 'The invisible war is a war between an oligarchy of priviledged people representing the interests of the supra-national speculative financial world and the ordinary, and the citizens of the single peoples and states' (Point 1 , electoral manifesto). The communicatyion style is highy informal, and aimed at mobilizing potential voters via appeals to fight a 'war'against the 'oligarchy' or the 'American-English-German finance' via a simplification of the solutions vis-à-vis complex problems. From an organizational perspective, Beppe Grillo - the leader - is mentioned only once, although the analysis of the "non-statute" is more telling, as it clearly states that the FSM 'represents a platform, a channel of discussion and consultation which originates (...) from the blog www.beppegrillo.it' (Regolamento FSM - Art. 1). Unlike traditional parties, there is no formalized membership nor are there organizational structures as 'membership to the Movement does not imply greater formalities than registering for a normal internet website (...) In order to become a member, a request will have to be sent to the website' (Art. 5). In other words, the website administrator (basically, Grillo and his informal collaborators) decide who can become a member, in a fully centralized and personalized fashion. For electoral purposes, the candidates will be designated following an electronic procedure which will be administered centrally and in 'unmediated' form (Art. 7). Thus, no mediation between the leader and the voters, and between the leader and the movement's members is offered. In conclusion, according to all our analytical dimensions (rules for the

\footnotetext{
${ }^{4}$ In order to mark its difference with respect to the other parties which have a Statute, the FSM has adopted a 'non-statute'.
} 
Table 4. Five Star Movement: ideological dimension

\begin{tabular}{lrlr}
\hline \hline 'Us' & $N$ & 'Them' & $N$ \\
\hline 2014 & & & \\
Italy & 18 & ECB/IMF/WB/EU & 9 \\
Our/nation & 14 & (Other) parties & 8 \\
Movement & 12 & Finance (i.e. financial actors) & 5 \\
Community & 5 & Germany & 4 \\
Citizens & 4 & Neoliberal(s) & 3 \\
People & 4 & & \\
\hline \hline
\end{tabular}

$\mathrm{ECB}=$ European Central Bank; IMF = International Monetary Fund; WB = World Bank; $\mathrm{EU}=$ European Union.

election/removal of the leader; tasks of the leader vs. other party bodies; rules for membership and member participation opportunities) the party statue clearly shows that in terms of leader power, a fully personalistic leadership and centrally organized functioning mode are guaranteed.

\section{Forza Italia: electoral manifestos and party statute}

Since the electoral manifestos of Forza Italia (FI) (Popolo della Libertà in 2009) is the programme of the European People's Party (EPP), ${ }^{5}$ we may think that populist signs - if present - may be of a European nature rather than of a national one. In fact, all the manifestos $(2004,2009$, and 2014) open with a foreword and picture of Berlusconi. Nevertheless, although specific populist traits can de detected for FI, we may also consider that these are reduced in comparison with what would occur in the case of domestic elections and domestic electoral manifestos (Verbeek and Zaslove, 2016).

In the 2004 electoral manifesto, with respect to the ideological dimension, it emerges quite clearly that the identity of the party is linked to individual freedom. The 'us', therefore, is linked to being free and the EU is seen as an instrument to support and reinvigorate freedom. FI sees itself as the motor of the EPP (cited 34 times) and part of Europe (cited 85 times). There is no strong identification with the 'people', whereas the 'them' is defined in terms of international terrorism (cited 10 times) and communism/communists (cited three times). Furthermore, crime is considered to be an issue, but 'criminals' are not stigmatized as in other electoral manifestos.

In terms of rhetoric, there is a strong legitimation of the party's novelty as a new actor (the party is characterized by the 'modernity of its manifesto' and as a party that 'does' things and not simply talks about things). Furthermore, there is a

${ }^{5}$ In 2004 and 2009, the party decided to present a manifesto that for the most part reproduced the platform of the EPP - differently from other Italian parties which tend to produce their own. 
delegitimation of all the other actors who 'do not have roots in Europe' and are a 'hybrid without any possible future no ideals (...), a product of the anomaly and the transformism of national parties which have survived to the historical decline of ideologies'.

The communication style is focussed on the fear that 'peace, freedom and democracy are not conquered once and for all, but they need to be defended every day from the overarching threats'. The idea of a 'battle' for freedom is supported by an institutional language, which is also slightly formal, although the solutions tend to be slightly simplistic as the complexities apparently, can be addressed by means of 'leadership, manifesto and alliances'.

With little surprise, the dimension where populism can be seen the most is the organizational one. Personalistic leadership is at the heart of the manifesto and 'Forza Italia is a solid collective entity thanks to the stenght of its leadership and the modernity of its manifesto'. Furthermore, the signature of Silvio Berlusconi opens the manifesto and in several parts, he talks directly to the voter ('I hope', 'I am convinced', etc.).

In the 2009 manifesto, which is presented by Il Popolo della Libertà (PdL), a new centre-right party founded by FI and other centre-right parties, there is a (limited) mention of the 'people' in the new name of the party and in the text (two times). 'Our people' is defined as people that 'work and produce' who want to belong to a liberal Europe, which is made of freedom, solidarity, and competition. 'Us' is defined in opposition to the 'them' represented by the establishment and also the other moderate parties which are criticized for not being able to relaunch domestic economies. Furthermore, there is a critique of the global financial market (cited seven times) that nevertheless does not become as strong as the one put forward by other parties, such as the NL.

In terms of rhetoric, there is a legitimation of 'new' actors (such as Partito della Libertà $(\mathrm{PdL})$ ) as the only ones who will be capable of taking the leadership of European citizens and the EU as a whole, but there is no evidence of delegitimation of other parties or institutions. Within the communication style there is no clear mention of fear or resentment, nor is the style so direct and colloquial as the 2004 manifesto. The arguments made in the manifesto are linked to the notion of 'responsibility' rather to the the idea of a reaction to a catastrophe (the adjective 'necessary' is mentioned nine times, while the verb 'need' is mentioned 18 times). Finally, there is no presentation of simplistic solutions to complex problems.

In terms of organization, there is a strong identification of the party with the leader ('Silvio') who is portrayed as a 'normal' person, a friend who will 'save' Italy, and the website forzasilvio. it is present on the banner from which the electoral manifesto can be downloaded.

In the 2014 electoral manifesto, from an ideological standpoint there is a greater mention of 'people' and no mention of 'citizens'. FI (the PdL party no longer exists at this point) wants to represent a liberal and Christian Europe and is willing to defend 'who needs to be helped', although there is no direct reference to a need to 
overcome an 'establishment' which is not even mentioned. Within the definition of 'them', together with Germany, the Euro and the ECB, there are 'the judges' who are considered to be responsible for most of the Italian problems. Berlusconi is mentioned 27 times, and a clear identification party-leader emerges from the electoral manifesto.

In terms of rhetoric, there is a delegitimation of the other political actors (also of the 'populist antieuropean movements' which - according to the electoral manifesto - are against a Germany-led Europe) and a broad critique of the 'system' as such. Furthermore, there is a legitimation of the 'new' actors represented by FI - not associated with any other parties as it was in 2009.

The communication style is a very direct and non-institutional one. The so-called 'Kit of the candidate' is packed with keywords and slogans, which should be used by the candidates for the European elections, and in several parts of the manifesto simple solutions to complex problems are offered (like the mentioned keywords and slogans in order to answer on several topics to citizens). In 2014, the style is a 'taboo breaker' one ('in moments like the one we currently are in (...) the rules need to be broken') and there is a use of words linked to fear, risk (two times), danger (two times), and crisis (five times).

Table 5. Forza Italia (FI): ideological dimension

\begin{tabular}{|c|c|c|c|}
\hline 'Us' & $N$ & 'Them' & $N$ \\
\hline \multicolumn{4}{|l|}{2004} \\
\hline Europe & 85 & International terrorism & 10 \\
\hline EPP & 34 & Crime(s) & 8 \\
\hline European Union & 28 & Immigrants/immigration (illegal) & 7 \\
\hline $\mathrm{FI} / \mathrm{Us}$ & 28 & Communists/ism & 3 \\
\hline Freedom & 24 & & \\
\hline Citizens & 15 & & \\
\hline USA & 5 & & \\
\hline \multicolumn{4}{|l|}{2009} \\
\hline Leader/party/PPE & 6 & Global financial system & 7 \\
\hline Young future generations & 4 & UE & 5 \\
\hline Family & 4 & Terrorism/ organized crime/illegal immigration & 4 \\
\hline People & 3 & & \\
\hline Citizen(s) & 2 & & \\
\hline \multicolumn{4}{|l|}{2014} \\
\hline Europe & 35 & Euro/ECB & 8 \\
\hline Berlusconi & 27 & German(s) & 5 \\
\hline EPP & 12 & Countries & 4 \\
\hline Ital* & 10 & Judges & 2 \\
\hline Freedom & 9 & Anti-European and populist movements & 2 \\
\hline People/everybody & 7 & Parties & 1 \\
\hline
\end{tabular}

$\mathrm{EPP}=$ European $\quad$ People's Party; $\mathrm{PPE}=$ Partito Popolare Europeo; $\mathrm{ECB}=$ European Central Bank. 
Similarly, to the previous manifestos, also in 2014 there is an identification between the party and the leader Berlusconi, who is mentioned 27 times and is considered to be the only politician who can save Italians from economic and social chaos.

In the party statute, the central role is played by the leader who is responsible for the nomination of several relevant organizational roles (namely, national and regional coordinators) and can also - on a discretionary basis - include in the party actors, which respond directly and solely to the President. In other words, once elected, the President of the party has very limited internal controls over his/hers activity, and this can be interpreted as another indicator of party-leader identification in a party where the leader has strong control over party members and 'personalizes' the relationship with the voters. In a nutshell, if we consider the key analytical dimensions we have applied to all the party statutes (rules for the election/ removal of the leader; tasks of the leader vs. other party bodies; rules for membership, and member participation opportunities) the highly personalistic leadership emerges quite clearly and all together it rivals only with the cases of the NL and FSM in terms of intensity of party leadership (Table 5).

\section{Varieties of Italian populism: discussion}

In this article, we have tried to empirically analyse populism not as a discrete concept (according to which one party can be defined as populist or not), rather as a continuous one, establishing a variety of populisms (i.e. different degrees of populism) within the Italian parties.

Table 6 shows how populism has progressed over the past decade in Italy. In 2014, we clearly see the presence of one political party (FSM) that displays strong populist traits according to our four dimensions. Furthermore, the additive index of populism among the Italian parties analysed in this contribution (i.e. adding all the total scores in columns obtained by each party per year) has jumped from 31 in 2004 to 53 in 2014 - an increase of over $70 \%$ - showing a generalized shift of the Italian political system towards populism. Especially in terms of rhetoric and communication style, there has been a growth in the 'degree' of populism exhibited by the Italian political parties. In particular, the NL emerges as the 'most' populist Italian party on all four dimensions throughout the period considered in the analysis. Only on the organizational dimension, this party is slightly 'less' populist in the 2014 manifesto and, more in general, in 2009. This is probably due to the fact that in those years the party was in power at the national level and that it gained for the first time EU Parliamentarians. In 2009, the NL shows less populist features, not reaching the previously registered maximum values on three out of four dimensions of the index, and this decrease possibly confirms the validity of the fringe party Euroscepticism hypothesis (e.g. Taggart, 1998) - according to which parties in government are less Eurosceptic - also for the interpretation of populism. In sum, as suggested more broadly by the literature (Biorcio, 2015), on the basis of the 
Table 6. Varieties of Italian populism: 2004-14

\begin{tabular}{|c|c|c|c|c|c|c|c|c|c|c|c|c|c|c|c|c|c|c|c|}
\hline \multirow[b]{2}{*}{ Dimensions of populism } & \multicolumn{19}{|c|}{ Italian parties } \\
\hline & $\begin{array}{c}\text { NL } \\
(2004)\end{array}$ & $\begin{array}{c}\text { NL } \\
(2009)\end{array}$ & $\begin{array}{c}\mathrm{NL} \\
(2014)\end{array}$ & $\begin{array}{l}\text { PD } \\
(2004)\end{array}$ & $\begin{array}{c}\text { PD } \\
(2009)\end{array}$ & $\begin{array}{c}\mathrm{PD} \\
(2014)\end{array}$ & $\begin{array}{c}\text { RIF } \\
(2004)\end{array}$ & $\begin{array}{c}\text { RIF } \\
(2009)\end{array}$ & $\begin{array}{c}\text { RIF } \\
(2014)\end{array}$ & $\begin{array}{l}\text { FSM } \\
(2014)\end{array}$ & $\begin{array}{c}\text { FI } \\
(2004)\end{array}$ & $\begin{array}{c}\text { FI } \\
(2009)\end{array}$ & $\underset{(2014)}{\text { FI }}$ & $\begin{array}{l}\text { UDC } \\
(2004)\end{array}$ & $\begin{array}{c}\text { UDC } \\
(2009)\end{array}$ & $\begin{array}{l}\text { UDC } \\
(2014)\end{array}$ & $\begin{array}{l}\text { IDV } \\
(2004)\end{array}$ & $\begin{array}{l}\text { IDV } \\
(2009)\end{array}$ & $\begin{array}{l}\text { IDV } \\
(2014)\end{array}$ \\
\hline $\begin{array}{l}\text { Ideology }(1-4 \text { scale }) \\
\text { People } \\
\text { Elites } \\
\text { Antagonism } \\
\text { Conspiracy }\end{array}$ & 4 & 3.5 & 4 & 0 & 0 & 0 & 0 & 0 & 0.5 & 4 & 1 & 1.5 & 3 & 0 & 0 & 1 & 3 & 1 & 3 \\
\hline $\begin{array}{l}\text { Rethoric (1-3 scale) } \\
\text { Delegitimation other actors/ } \\
\text { proposals } \\
\text { Delegitimation institutions } \\
\text { Legitimation new actors }\end{array}$ & 3 & 2 & 3 & 0 & 1 & 0 & 0 & 0 & 0 & 3 & 2 & 0.5 & 2 & 0 & 0 & 0.5 & 2 & 1.5 & 2 \\
\hline $\begin{array}{l}\text { Style (1-4 scale) } \\
\text { Resentment } \\
\text { Direct and non-institutional } \\
\text { Strong emotions (fear, } \\
\text { enthusiasm, etc.) } \\
\text { Easy solutions to complex } \\
\text { problems }\end{array}$ & 4 & 3 & 4 & 0 & 0 & 0 & 0 & 0 & 0 & 4 & 1 & 0.5 & 3.5 & 0 & 0 & 0 & 2 & 1 & 2 \\
\hline $\begin{array}{l}\text { Organization (1-4 scale) } \\
\text { Leader direct mentions } \\
\text { Leader role description } \\
\text { Leader relationship with } \\
\text { voter/party members } \\
\text { Statute powers }\end{array}$ & 4 & 4 & 3 & 0 & 0 & 0 & 0 & 0 & 0.5 & 4 & 4 & 4 & 4 & 1 & 0 & 0 & 0.5 & 1.5 & 2.5 \\
\hline $\begin{array}{l}\text { Additive index of populism } \\
\text { Total }(N=15)\end{array}$ & 15 & 12.5 & 14 & 0 & 1 & 0 & 0 & 0 & 1 & 15 & 8 & 6.5 & 12.5 & 1 & 0 & 1.5 & 7.5 & 5 & 9.5 \\
\hline
\end{tabular}

$\mathrm{NL}=$ Northern League; PD = Democratic Party; RIF = Rifondazione Comunista; FSM = Five Star Movement; FI = Forza Italia; UDC = Unione di Centro; IDV = Italia dei Valori. 
European electoral manifestos and party statutes an all-encompassing definition of populism can easily be applied to the case of NL.

If in Italy the populist champion is represented by NL during the period considered, also the FSM shows a high 'degree of populism', reaching the top score of 15 on the populism index, as Table 6 indicates. Of course, any generalization regarding the FSM may be premature since the general elections of 2013 and the European elections of 2014 are the first truly relevant elections in which the FSM competed. In a diacronical perspective, it will be interesting to conduct future research in order to empirically monitor the FSM and see if this strong populist imprinting will continue over time. Continuing our analysis, also FI ranks high in our 'populism index', especially in 2014 when it equals the values of the NL, and particularly in terms of style and organization. ${ }^{6}$ Similarly, although with slightly lower values, it is interesting to highlight the result of the IDV party, especially in 2004 and 2014, and above all on the ideological dimension (in spite the fact that commonly this party is not included by scholars among populist parties). ${ }^{7}$ Also the UDC, differently than the other heirs of the historical Christian-Democratic massparty, shows some populist traits in organization (e.g. concerning the mentioning and presentation of the leader in the manifesto not his power by statute), ideology and even rhetoric [accounting for a total score of 2.5 in the period considered vs. 1 of the PD and RIF, respectively]. Finally, no significant signs of populism can be found in the manifestos and statutes of the heirs of old Communist party (RIF) nor - contrary to some other findings (Biorcio, 2015) - in the PD which is a 'joint venture' of some heirs of both the Christian-Democratic and the Communist Party.

In sum, these results confirm that considering populism as a unidimensional and dichotomic concept does not allow a full understanding of the variations among populist configurations and (empirical) manifestations. Instead, our 'populism index' seems to be a very fruitful tool for such a purpose.

\section{Conclusion}

The exercise conducted in this article is particularly important because, on the one hand, looking at the vast literature on the concept of populism, it goes beyond many valuable attempts aimed at finding ideal definitions but which are then rarely tested with empirical indicators; on the other hand, because it goes beyond most of the existing empirical studies on attributes associated with populism which address only one aspect at time, that is developing measurable concepts of populism by

\footnotetext{
${ }^{6}$ In 2004, the values of FI for ideology and style are probably biased (i.e. lower than expected) since - as already said - in this year the party decided to present a manifesto that for the most part reproduced the platform of the EPP. Some studies describe the attitudes of FI on EU issues less Europeist than this platform seems to suggest (Conti and Memoli, 2009).

${ }^{7}$ Also in the case of the IDV we have to consider that probably we coded 'biased' values very prudentially in appraising the dimensions of our index, since this party in 2004 and 2009 presented a reduced electoral manifesto with reference to the EU (Conti and Memoli, 2009).
} 
narrowing it (Jagers and Walgrave, 2007). We claim that our research effort may be able to advance populism research in three respects: (a) providing a comprehensive picture of the evolution of the Italian party landscape over the past 10 years in terms of populistic tendencies; (b) showing how Italian political parties' electoral manifestos have been affected by their reading of the financial and economic crisis; (c) and, most importantly, offering an analytical framework for an accurate and comprehensive description of populism in terms of ideology, rhetoric, communication style, and organization, in accordance with the suggestion that 'the term populism needs to be defined and operationalized more precisely and in a relative manner, providing the opportunity of variation among political parties across time and space' (de Raadt et al., 2004: 1). More specifically, we have considered populism not as a 'syndrome to be cured' but as an observable phenomenon which may concern all political parties present in a given domestic political community.

As for the first aspect, we argue that the careful analysis of the Italian case suggests how the crisis (and the political answers which followed) has offered a great opportunity for fully or not-so-fully populist parties to grow over time, this confirming our working hypothesis which opened the article on the impact of the crisis on voters. Not only a new populist political party was born (the FSM) but also most of the pre-existing political parties have accentuated their populist traits. Furthermore, in our research, we have observed that a specific orientation of populist parties towards Europe and the EU has emerged as (i) most of the populist parties analysed show a clear anti-EU attitude; (ii) some of the parties' success is based on a xenophobic and anti-immigration form of mobilization (e.g. in the case of the NL); and (iii) most of the populist parties show a clear anti-establishment attitude. This said, however, we have to underline that differently than the other Italian parties analysed, two parties - NL and FSM - can be linked to aspects of nationalist discourse, and this is especially true in relation to Europe. Some further (typological-categorical) distinctions, seem to be therefore in order to disentagle the type of populism found, as for instance that between more 'exclusionary' (which would be closer to the NL) and more 'inclusionary' (5SM) (Mudde and Kaltwasser, 2013). Further research is needed to explore these aspects in details.

The second finding regards the reasons for such increase. Our hypothesis was that the growth of populist traits in the Italian party system could be explained by an 'exogenous shock' such as the financial and economic crisis. And indeed, beyond the quantitative analysis, the manifestos show quite clearly that one of the main triggers for the consolidation of populist traits is linked to the growing 'resentment' that the crisis has created among Italians. Especially, if we consider the differences between the 2004, and the 2009 and 2014 electoral manifestos, criticism towards the management of the crisis (especially in the cases of NL, IDV, and FSM) is very clear and the electoral manifestos are full of accusations against the EU, the EU Commission (which becomes a key target especially in the 2014 electoral manifestos), the ECB, 'multinationals', financial actors, etc. Put differently, the crisis becomes an evident trigger for the consolidation of populist traits in terms of the 
identification of 'them', that is the EU institutions and leaders, as EU institutional actors are seen as responsible of inaction, or of 'wrong' action under the form of austerity, and therefore to be sanctioned. Furthermore, following these lines of thought, as mentioned above, it could be argued that FSM would never have been so succesful without the crisis. To be sure, even if we consider the other traditional explanations of populism growth - crisis of representative democracy (Taggart, 2000; Mény and Surel, 2002); mix of modernization crisis, insecurity, and authoritarian legacies (Mudde, 2007); social and economic factors (Rydgren, 2005 ) - the recent European financial and economic crisis can be considered as one of the main triggers for the populist 'boom' as the other above mentioned variables require more than 10 years to become highly influencial. In this regard, our findings confirm the link between populism and Euroscepticism and political protest as suggested by Canovan (1999) who argues that populist movements should be seen as a shadow casted by democracy itself, as they find available space to rise and grow in power in the gap between the two aspects of democracy, the facet of redemption (proposing salvation through politics involving the power of people through elections) and the facet of pragmatism (institutions aimed at limiting, constituting, and organizing power).

Lastly, we believe that our methodology and overall approach can be applied accross time and space in order to grasp the 'degree of populism' in any given political system. In this respect, the aim of our research design has been not to take a simple snapshot of Italian populism as expressed in the European elections, but rather to provide an updated trajectory of Italian populism through a theoretical and empirical analysis which may be of interest also for other studies.

\section{Acknowledgement}

The research received no grants from public, commercial, or non-profit funding agency.

\section{Supplementary material}

To view supplementary material for this article, please visit http://dx.doi.org/ 10.1017/ipo.2016.6

\section{References}

Abt, K. and R. Stefan (2007), 'Populism versus democracy', Political Studies 55: 405-424.

Albertazzi, D. and D. McDonnell (2015), Extremism and Democracy: Populist Parties in Power: Italian and Swiss Success Stories, UK: Routledge.

Barney, D. and D. Laycock (1999), 'Right-Populists and Plebiscitary Politics in Canada', Party Politics 5: 317-339.

Betz, H.-G. (1994), Radical Right-Wing Populism in Western Europe, London: MacMillan.

Biorcio, R. (2015), Il populismo nella politica italiana, Milano: Mimesis. 
Caiani, M. and D. della Porta (2011), 'The elitist populism of the extreme right: a frame analysis of extreme right wing discourses in Italy and Germany', Acta Politica 46(2): 180-202.

Campus, D. (2006), L'antipolitica al governo. De Gaulle, Reagan, Berlusconi, Bologna: Il Mulino.

Canovan, M. (1999), 'Trust the people! Populism and the two faces of democracy', Political Studies 47(1): 2-16.

Carlotti, B. (2015), 'Linking European integration, Euroscepticism and populism: theoretical reflections and empirical measurement'. Paper presented at the ECPR Conference, August 31-September 2, Montreal, Canada.

Conti, N. and V. Memoli (2009), 'Le posizioni programmatiche dei partiti italiani in occasione delle elezioni europee'. Paper presented at the SISP Conference, September 11-13, Rome.

de Raadt, J., H. David and K. Andrè (2004), 'Varieties of populism: an analysis of the programmatic character of six European parties’. Working papers, Political Science No. 2004/04 ISSN 1569-3546, Vriij University Amsterdam, Amsterdam.

Di Tella, T. (1997), 'Populism into the twenty-first Century', Government and Opposition 32(2): 187-200.

Eatwell, R. (2003), 'The theories of the extreme right', in P. Merkl and L. Weinberg (eds), Rightwing Extremism in the Twenty-First Century, London: Frank Cass, pp. 47-74.

Freeden, M. (1998), 'Is nationalism a distinct ideology?', Political Studies 46(4): 748-765.

Jagers, J. and S. Walgrave (2007), 'Populism as political communication style: an empirical study of political parties' discourse in Belgium', European Journal of Political Research 46: 319-345.

Jansen, R. (2011), 'Populist mobilization. A new theoretical approach to populism', Sociological Theory 29(2): 75-96.

Kriesi, H. (2014), 'The populist challenge', West European Politics 37(2): 361-378.

Laclau, E. (2005), La razón populista, Buenos Aires: Fondo de Cultural Económica.

Laycock, D. (2005), 'Populism and the new right in English Canada', in F. Panizza (ed.), Populism and the Mirror of Democracy, London: Verso, pp. 172-203.

Leconte, C. (2015), 'From pathology to mainstream phenomenon: reviewing the Euroscepticism debate in research and theory', International Political Science Review 36(3): 250-263.

Luther, K.R. (2003), 'The FPÖ: from populist protest to incumbency', in P.H. Merkl and L. Weinberg (eds), Right-Wing Extremism in the 21st-Century, London: Frank Cass, pp. 23-46.

Mair, P. (2002), 'Populist democracy vs. party democracy', in Y. Mény and Y. Surel (eds), Democracies and the Populist Challenge, London: Palgrave Macmillan, pp. 81-98.

March, L. (2007), 'From Vanguard of the Proletariat to Vox Populi: left-populism as a "shadow" of contemporary socialism', SAIS Review 27(1): 63-77.

Mazzoleni, G. (2003), 'The media and the growth of neo-populism in contemporary democracies', in G. Mazzoleni, J. Stewart and B. Horsfield (eds), The Media and Neo-Populism. A Contemporary Comparative Analysis, Westport, CT: Praeger, pp. 4-27.

Mazzoleni, G., S. Julianne and H. Bruce (eds) (2003), The Media and Neo-Populism: A Contemporary Comparative Analysis, Westport, CT: Praeger Publishers.

Mény, Y. and Y. Surel (2002), 'The constitutive ambiguity of populism', in Y. Mény and Y. Surel (eds), Democracies and the Populist Challenge, London: Palgrave Macmillan, pp. 1-21.

Mudde, C. (2002), 'Extremist movements', in Heywood P., et al. (eds), Developments in West European Politics, Basingstoke: Palgrave, pp. 135-148.

— (2004), 'The populist Zeitgeist', Government and Opposition 39(3): 541-563.

- (2007), Populist Radical Right Parties in Europe, Cambridge: Cambridge University Press.

Mudde, C. and C.R. Kaltwasser (2013), 'Exclusionary vs. inclusionary populism: comparing the contemporary Europe and Latin America', Government \& Opposition 48(2): 147-174.

Pasquino, G. (2007), 'The five faces of Silvio Berlusconi: the knight of antipolitics', Modern Italy 1(12): 39-54.

— (2008), 'Populism and democracy', in D. Albertazzi and D. McDonnell (eds), Twenty-First Century Populism: The Spectre of Western European Democracy, Houndmills: Palgrave Macmillan, pp. 122-138.

Ruzza, C. and S. Fella (2009), Re-Inventing the Italian Right: Territorial Politics, Populism and 'Post-Fascism', Milton Park, Abingdon, Oxon and New York: Routledge. 
Rydgren, J. (2003), 'Meso-level reasons for racism and Xenophobia', European Journal of Social Theory 6(1): 45-68.

- (2005), 'Is extreme right-wing populism contagious? Explaining the emergence of a new party family', European Journal of Political Research 44: 413-437.

- (2007), 'The sociology of the radical right', Annual Review of Sociology 33: 241-262.

Taggart, P. (1998), 'A touchstone of dissent: Euroscepticism in contemporary Western European party systems', European Journal of Political Research 33(3): 363-388.

- (2000), Populism, Buckingham: Open University Press.

- (2004), 'Populism and representative politics in contemporary Europe', Journal of Political Ideologies 9(3): 269-288.

Tarchi, M. (2002), 'Populism Italian style', in Y. Mény and Y. Surel (eds), Democracies and the Populist Challenge, New York: Palgrave, pp. 84-99.

(2015), L'Italia populista, Bologna: Il Mulino.

Treib, O. (2014), 'The voter says no, but nobody listens: causes and consequences of the Eurosceptic vote in 2014 European elections', Journal of European Public Policy 21(20): 1541-1554.

Verbeek, B. and A. Zaslove (2016), 'Italy: a case of mutating populism?', Democratization 23(2): 304-323.

Verney, S. and A. Bosco (2013), 'Living parallel lives: Italy and Greece in an age of austerity', South European Society and Politics 18(4): 397-426.

Weyland, K. (2001), 'Clarifying a Contested Concept: Populism in the Study of Latin American Politics', Comparative Politics 34(1): 1-22.

Zaslove, A. (2008), 'Here to stay? Populism as a new party type', European Review 16(3): 319-336. 


\section{Appendix}

Table A1. Codebook used for the analysis

\begin{tabular}{|c|c|c|c|}
\hline \multicolumn{4}{|c|}{ Populism } \\
\hline Attributes & Description & Codified indicators $(0-1$, string $)$ & Example \\
\hline \multirow[t]{8}{*}{ Rhetoric } & $\begin{array}{l}\text { Instrumentalization of diffuse public sentiments of } \\
\text { anxiety and disenchantment }\end{array}$ & \multirow{8}{*}{$\begin{array}{l}\text { Delegitimation political institutions } \\
\text { Delegitimation other political actors and } \\
\text { their proposals } \\
\text { Legitimation of new political actors }\end{array}$} & $\begin{array}{l}\text { 'The EU is a dictatorship without } \\
\text { legitimation' }\end{array}$ \\
\hline & $\begin{array}{l}\text { The sublimation of the 'redemptive' side of politics } \\
\text { (opposed to the 'pragmatic' side; Canovan, 1999) }\end{array}$ & & 'The other parties are totally \\
\hline & The power of common people vs. legitimacy of the & & unresponsible’ \\
\hline & current political establishment (a discursive & & 'We are the saviors of the nation' \\
\hline & challenge to 'institutions’; Laclau, 2005) & & \\
\hline & Challenge to both the political and economic & & \\
\hline & $\begin{array}{l}\text { establishments and elite values of the type held by } \\
\text { opinion-formers in the academia and the media' } \\
\text { (Canovan, 1999: 3) }\end{array}$ & & \\
\hline & $\begin{array}{l}\text { The primary goal of these statements is to } \\
\text { 'delegitimise established structures of interest } \\
\text { articulation and aggregation' (Barney and Laycock, } \\
\text { 1999: 321) }\end{array}$ & & \\
\hline \multirow[t]{5}{*}{ Ideology } & $\begin{array}{l}\text { Society: two homogeneous and antagonistic groups/ } \\
\text { bodies ('the pure people' vs. 'the corrupt elite') }\end{array}$ & & $\begin{array}{l}\text { Number of time 'people' (or related } \\
\text { concepts) is mentioned }\end{array}$ \\
\hline & $\begin{array}{l}\text { Manichean: for the people against the elite } \\
\text { (Mudde, 2004) }\end{array}$ & $\begin{array}{l}\text { People } \\
\text { Elites }\end{array}$ & \multirow[t]{4}{*}{ Etc. $^{a}$} \\
\hline & The structure of power in the society: antagonistic & Antagonistic relation & \\
\hline & $\begin{array}{l}\text { relations between the people and the elite; the idea of } \\
\text { restoring popular sovereignty }\end{array}$ & Conspiracy theory & \\
\hline & Economic protectionism & & \\
\hline
\end{tabular}


Table A1. (Continued)

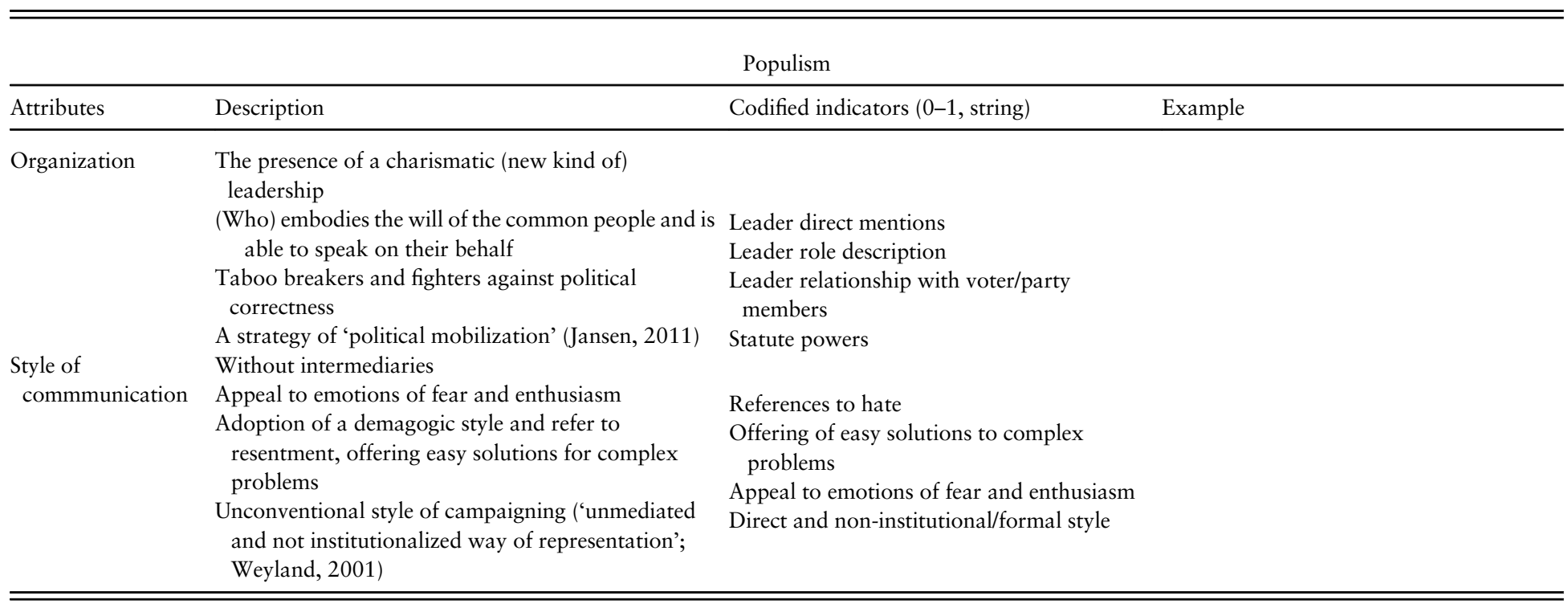

$\mathrm{EU}=$ European Union.

${ }^{a}$ For the way we measured each indicators please see the methodological sections, plus the footnotes of the tables in the text. 